\title{
Perancangan Website Penyedia Informasi Promosi dan Diskon
}

\author{
Mesri Silalahi $^{\mathrm{a} 1}$, Saut Pintubipar Saragih ${ }^{\mathrm{a} 2}$ \\ a Program Studi Sistem Informasi, Universitas Putera Batam \\ Jalan R. Soeprapto, Muka Kuning, 29452, 0823-9128-7111 \\ ${ }^{1}$ mesripbegmail.com \\ ${ }^{2}$ sautpin.upbegmail.com
}

\begin{abstract}
Abstrak
Perkembangan internet yang sangat pesat memiliki peran yang sangat penting dalam segala bidang, terlebih pada saat pandemi seperti saat ini berbagai hal dilakukan dengan menggunakan internet, termasuk dalam penyampaian informasi promosi dan diskon produk perusahaan tertentu. Penelitian ini bertujuan untuk merancang dan membangun sistem informasi berupa website yang menyediakan informasi promosi dan diskon. Dalam perancangan sistem digunakan model waterfall, dengan tahapan mulai dari analisis, perancangan, pengkodean hingga pengujian. Hasil penelitian menunjukkan bahwa dengan adanya website yang menyediakan informasi promosi dan diskon, konsumen dan calon konsumen di Kota Batam dapat mengetahui berbagai informasi promosi dan diskon dengan cepat tanpa harus pergi ke lokasi toko atau pemasar secara langsung sehingga dapat menghemat biaya, tenaga dan Selain itu, mereka juga menghindari keramaian dalam upaya menghindari berbagai penyakit atau virus. Pemasar juga dapat menyampaikan berbagai informasi produknya dengan mudah tanpa harus mencetak brosur atau media lain secara manual sehingga dapat menghemat biaya promosi.
\end{abstract}

Kata kunci: Diskon, Produk, Promosi, Website

\section{Website Designing for Promotion and Discount Information Providers}

\begin{abstract}
The very rapid development of the internet has a very important role in all fields, especially during the current pandemic, various things are done using the internet, including in conveying promotional information and discounts on certain company products. This study aims to design and build an information system in the form of a website that provides information on promotions and discounts. In designing the system, the waterfall model is used, with stages starting from analysis, design, coding to testing. The results showed that with a website that provides promotional and discount information, consumers and potential consumers in Batam City can find out various promotional information and discounts quickly without having to go to the store or marketer location directly so that they can save costs, energy and time, besides also they can avoid crowds in an effort to avoid various diseases or viruses. Marketers can also convey various information on their products easily without having to print brochures or other media manually so they can save on promotional costs.
\end{abstract}

Keywords: Discount, Product, Promotion, Website

\section{PENDAhUluan}

Perkembangan internet yang sangat pesat mempunyai peranan yang sangat penting dalam segala bidang khsusnya di masa pandemi saat ini, berbagai hal dilakukan dengan menggunakan internet termasuk dalam menyampaikan informasi promosi dan diskon produk-produk perusahaan tertentu. Promosi yaitu salah satu unsur pemasaran yang digunakan untuk memberitahukan, membujuk, dan mengingatkan tentang produk perusahaan [1]. Kegiatan promosi dilakukan dengan tujuan untuk menjembatani antara perusahaan dengan konsumen atau pengguna. Kegiatan promosi merupakan bagian dari strategi pemasaran yang dibutuhkan usaha bisnis, baik usaha kecil maupun menengah [2]. Promosi dikatakan berhasil jika perusahaan dapat menyampaikan pesan yang ingin disampaikan sehingga dapat diterima masyarakat sebagai konsumen/ pengguna serta tepat sasaran sesuai dengan yang diharapkan [3]. Diskon menurut Tjiptono (2008:166), merupakan potongan harga yang diberikan oleh penjual serta sebagai penghargaan karena telah membeli suatu produk [4]. Terdapat 5 macam diskon atau potongan harga, antara lain: potongan harga tunai, potongan kuantitas diberikan saat konsumen membeli dalam jumlah yang banyak, potongan harga fungsional diperuntukkan bagi anggota yang mempunyai fungsi tertentu, potongan harga musiman hanya diberikan pada saat tertentu, serta potongan harga biasa [5].

Di Batam, banyak toko-toko ataupun departemen store yang mengadakan promosi dan pemberian diskon setiap 
hari, berbagai produk ditawarkan dengan harga promosi ataupun diskon mulai dari kebutuhan pokok, pakaian, perlengkapan anak sekolah maupun barang-barang lainnya. Program promosi dan diskon yang dilakukan merupakan salah satu strategi perusahaan untuk menciptakan minat beli demi meningkatkan penjualan produk atau jasa [6]. Konsumen biasanya dapat mengetahui informasi promosi dan diskon dengan mendatangi secara langsung toko yang bersangkutan, hal ini mengakibatkan banyaknya antrian apalagi dengan kondisi saat ini dimana adanya pandemi Covid-19 mengharuskan untuk selalu menjaga jarak. Oleh karena itu pelanggan seringkali sulit untuk mengetahui berbagai informasi tentang produk, dikarenakan media promosi terbatas dan kurang fleksibel, selain itu juga adanya hambatan personalisasi, dan biaya operasional berupa biaya transposrtasi yang menjadi penghalang untuk memperoleh informasi promosi dan diskon [7].

Dalam penyampaian informasi promosi dan diskon oleh pihak toko, retail, ataupun departement store kebanyakan dilakukan dengan membagi-bagikan brosur, namun hal ini dirasa kurang efektif dikarenakan ketika brosur-brosur dibagikan sering sekali tidak dibaca sehingga terbuang begitu saja sedangkan pihak toko atau bidang usaha lainnya sudah mengeluarkan biaya untuk pembuatan brosur, demikian halnya dengan pemasangan poster, cara penyampaian informasi seperti ini cukup baik namun kurang fleksibel dikarenakan tidak semua orang dapat melihat poster yang dibuat.

Selain penyampaian informasi secara langsung, banyak juga toko, departemen store maupun perusahaan yang memanfaatkan media sosial dalam menyampaikan informasi promosi dan diskon. Jenis media sosial yang dikenal dan diminati oleh masyarakat sangat beragam, diantaranya Youtube, Facebook, Instagram, Twitter, WhatsApp dan lain-lain [8], setiap media sosial mempunyai karakteristik tersendiri untuk melakukan kegiatan promosi kepada pelanggan [9]. Penggunaan sosial media sebagai sarana promosi dan penyampaian informasi diskon memungkinkan pemasar atau toko-toko berbagi informasi menjadi lebih mudah [10], namun terkadang strategi promosi dengan memuat iklan perusahaan melalui media sosial dirasakan pengguna sosial media sangat mengganggu dikarenakan pengguna mengakses sosial media dengan tujuan untuk berhubungan dengan orang lain secara online sehingga cara untuk menyampaikan informasi promosi dan diskon ini dirasakan masih kurang efektif oleh pemasar maupun pengguna sosial media itu sendiri [11].

Agar informasi promosi dan diskon dapat tersampaikan dengan baik maka dibutuhkan sebuah wadah berupa website yang fokus dalam penyampaian informasi promosi dan diskon sehingga upaya yang telah dilakukan para pemasar tidak sia-sia dan konsumen ataupun calon konsumen dapat memperoleh informasi dengan cepat sehingga mereka dapat melakukan pembelian berbagai produk-produk yang dibutuhkan dengan harga-harga ekonomis.

Beberapa penelitian mengungkapkan bahwa efektivitas penggunaan website dalam mendongkrak peningkatan volume penjualan dan mempromosikan produk-produk industri cukup tinggi [12], sehingga kegiatan promosi dan dan diskon penjualan nantinya dapat secara signifikan berdampak pada perilaku konsumen dan keputusan pembelian mereka [13]. Oleh karena itu penelitian ini ditujukan untuk merancang sebuah website penyedia informasi dan promosi dikarenakan website sejenis ini masih belum ada di Kota Batam.

\section{METODOLOGI PENELITIAN}

Metode penelitian yang digunakan pada website penyedia informasi promosi dan diskon ini menggunakan model waterfall, hal ini dikarenakan metode waterfall merupakan model pengembangan sistem informasi yang sistematik dan sekuensial [14], model SDLC air terjun (waterfall) sering juga disebut model sekuensial linier (sequential linear) atau alur hidup klasik (classic life cycle) [15]. Tahapan-tahapan pada model waterfall yang digunakan sebagai berikut:

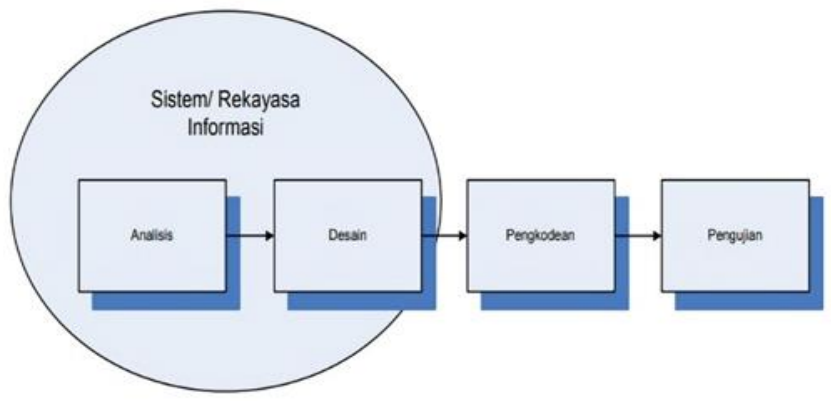

Gambar 1. Model waterdall (Sukamto dan Shalahuddin (2013)

1. Analisis

Sebelum analisis data, terlebih dahulu dilakukan pengumpulan data dengan cara melakukan observasi prilaku konsumen di Kota Batam, studi kepustakaan mengenai hal-hal yang berkaitan dengan promosi dan diskon di Kota Batam serta mengunjungi beberapa toko, ritel dan departemen store sebagai acuan sumber utama informasi di website promosi dan diskon di Kota Batam, selanjutnya dilakukan analisis kategori apa yang akan diinformasikan, bentuk penyajian informasi dan sebagainya.

2. Desain

Dalam mendesain website promosi dan diskon di Kota Batam, digunakan beberapa diagram yaitu Use Case diagram, Activity diagram, serta Entity Relationship Diagram (ERD) untuk menjelaskan apa yang akan dilakukan oleh sistem serta hubungan dengan proses proses yang ada pada sistem

3. Pembuatan kode program

Desain yang sudah dibuat selanjutnya ditranslasikan ke dalam program perangkat lunak. Hasil dari tahap ini adalah program komputer sesuai dengan desain yang telah dibuat pada tahap desain.

4. Pengujian

Pengujian yang dilakukan difokuskan pada perangkat lunak secara lojik dan fungsional dan memastikan bahwa semua bagian sudah diuji. Hal ini dilakukan untuk meminimalisir kesalahan (error) dan memastikan keluaran yang dihasilkan sesuai dengan yang diinginkan. 


\section{HASIL DAN PEMBAHASAN}

\section{A. Hasil Penelitian}

Sistem yang dirancang dikhususkan untuk mengurangi penggunaan brosur, poster, baliho dan yang lainnya yang sejenis sehingga dapat mengurangi biaya bagi pemasar untuk menyampaikan informasi informasi promosi dan diskon, hal sama juga akan dirasakan oleh konsumen, konsumen tidak perlu mendatangi ritel untuk mengetahui barang apa saja yang didiskon. Konsumen hanya perlu mengakses piranti keras mereka dan mengunjungi website yang dibangun, selanjutnya konsumen dapat melihat daftar promosi beserta barang-barang yang sedang diskon beserta syarat dan besaran diskonnya. Konsumen juga bisa membandingkan harga dari retail satu ke retail lainnya atau konsumen bisa memutuskan untuk belanja di ritel yang banyak mengeluarkan promosi yang menarik.

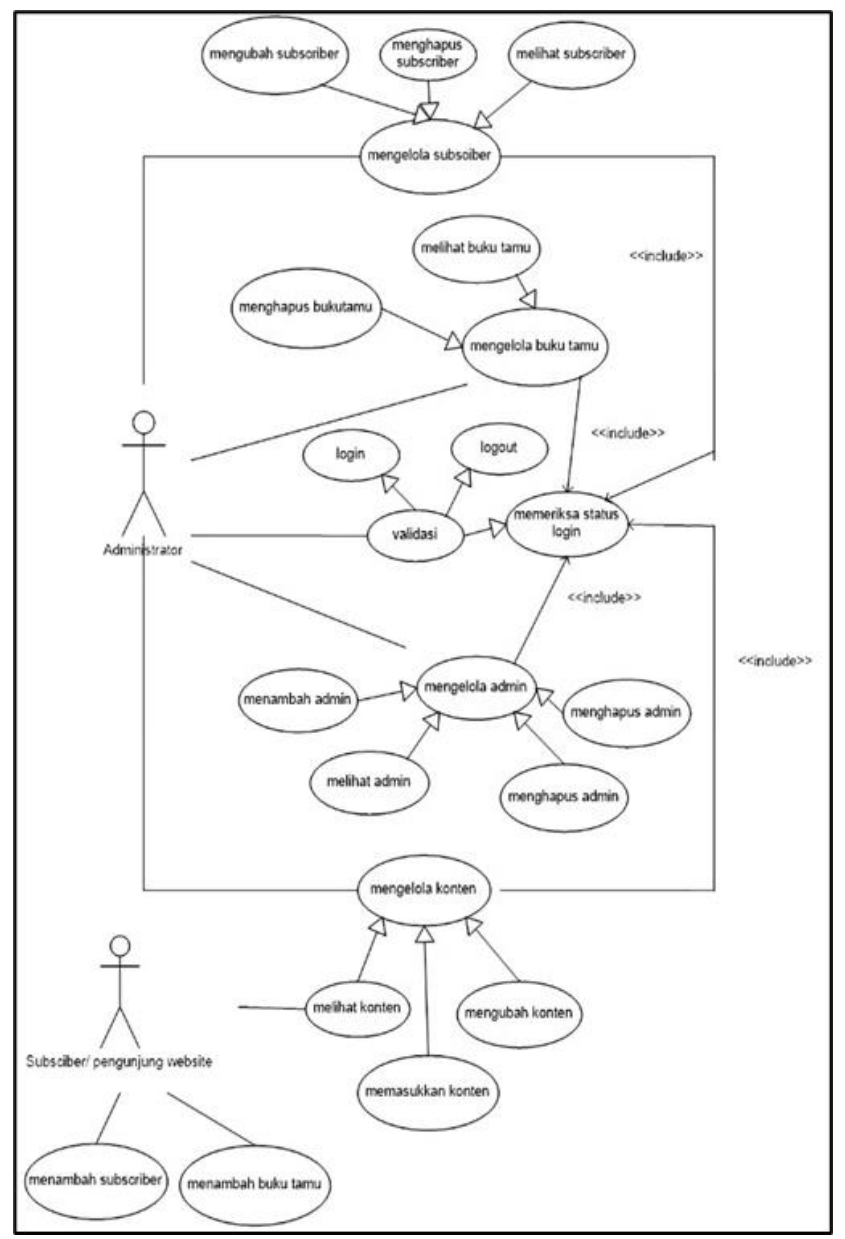

Gambar 2. Usecase diagram

Gambar 2, menunjukkan Use case diagram yang digunakan pada website penyedia informasi promosi dan diskon. Pada use case yang dirancang terdapat dua aktor yaitu aktor administrator dan subscriber atau pengunjung website. Administrator yaitu orang yang bertanggunjawab mengelola konten, mengelola admin, validasi login user, mengelola subscriber. Aktor subscriber merupakan pengunjung website penyedia informasi promosi dan diskon. Subscriber dalam website yang dibangun ditujukan untuk siapa saja yang mengunjungi website baik itu pemasar, konsumen ataupun calon konsumen.

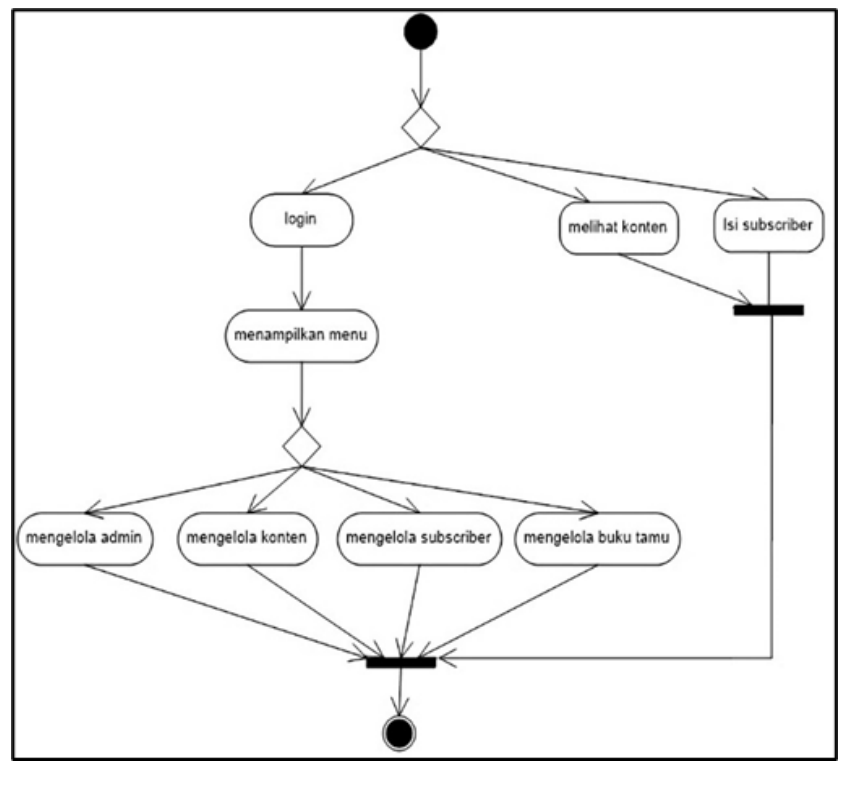

Gambar 3. Activity diagram

Activity diagram yang dirancang untuk website penyedia informasi promosi dan diskon seperti pada gambar 3 digunakan untuk memodelkan event-event atau aliran aktivitas yang terjadi dalam usecase diagram.

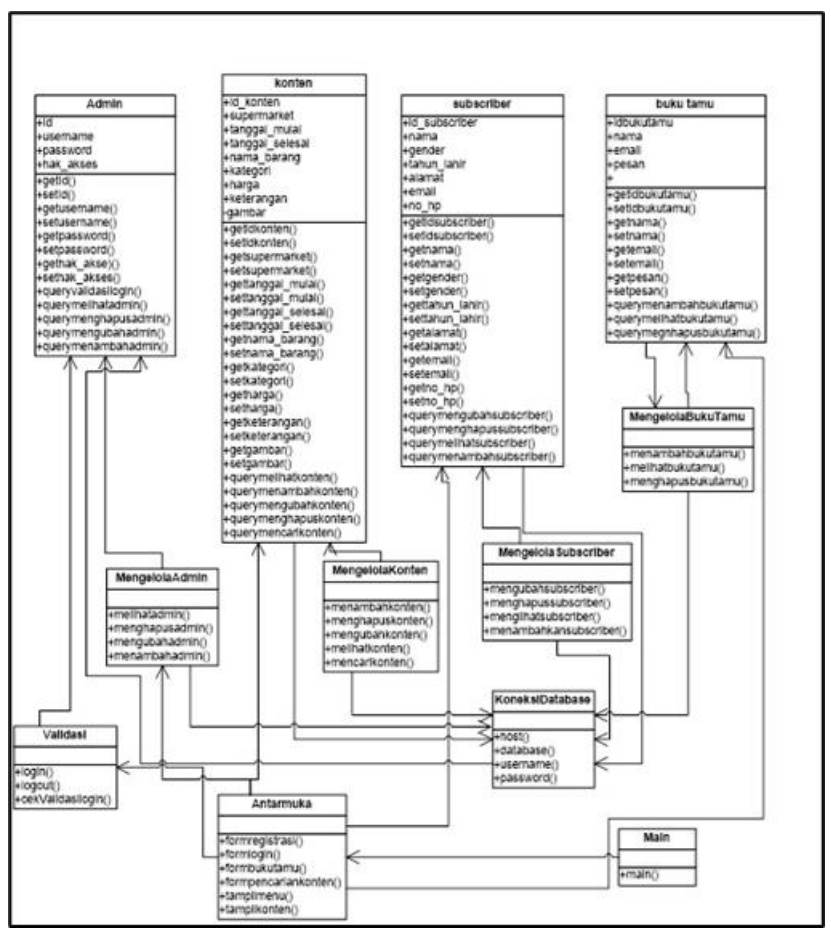

Gambar 4. Class diagram

Class diagram seperti yang ditampilkan pada gambar 4 digunakan untuk menampilkan beberapa kelas yang ada dalam website penyedia informasi promosi dan diskon. Class diagram yang dirancang menunjukkan hubungan dan kolaborasi antar kelas untuk mencapai tujuan yang ditetapkan. 


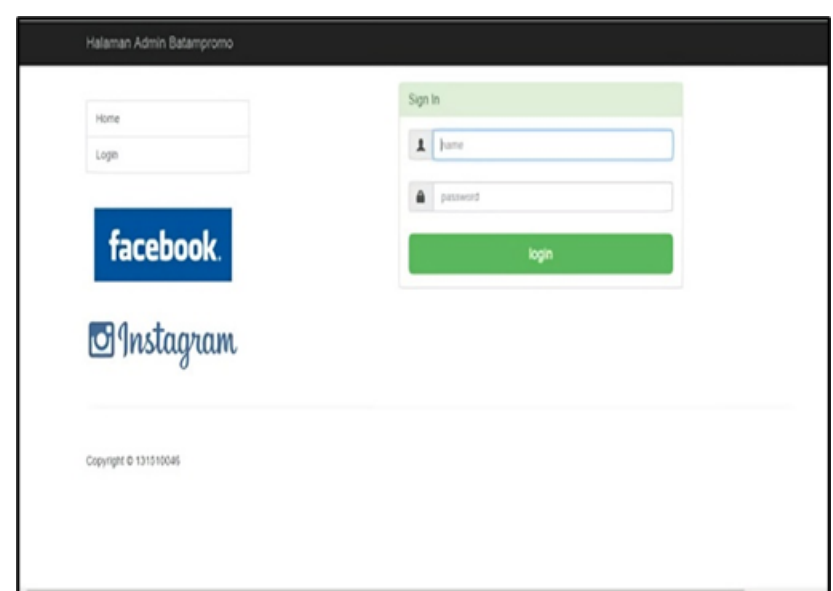

Gambar 5. Halaman login admin

Gambar 5 menunjukkan tampilan dari halaman login admin website penyedia informasi promosi dan diskon. Admin login dari halaman web ini dengan memasukkan user name dan password.

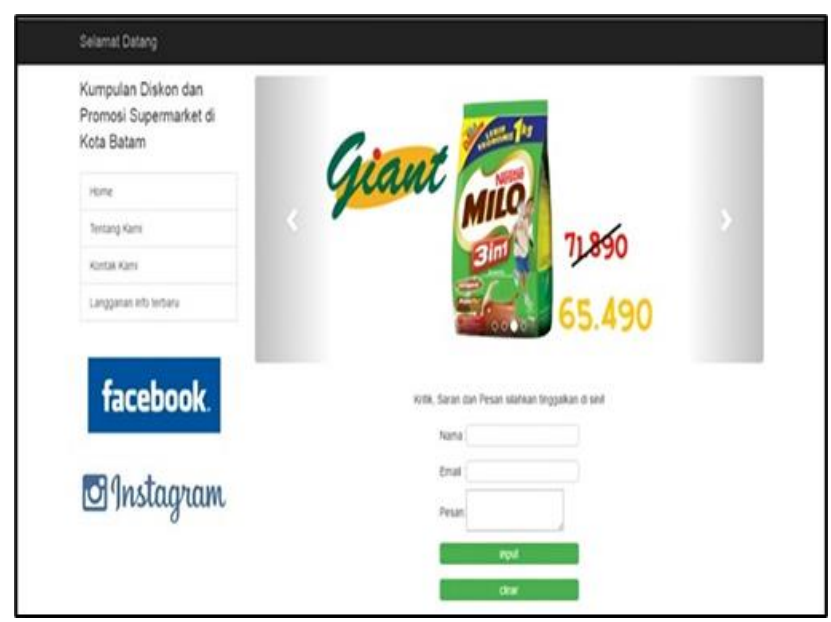

Gambar 6. Halaman input buku tamu

Gambar 6 merupakan tampilan halaman input buku tamu, halaman ini ditujukan untuk penyampaian berbagai kritik, saran, masukan ataupun pesan-pesan lainnya. Ketika pemasar mengalami kendala dalam mengupload produk yang dipasarkan maka mereka dapat menyampaikan lewat laman ini, demikian halnya ketika konsumen mengalami berbagai kendala maka dapat menyampaikannya melalui laman ini.

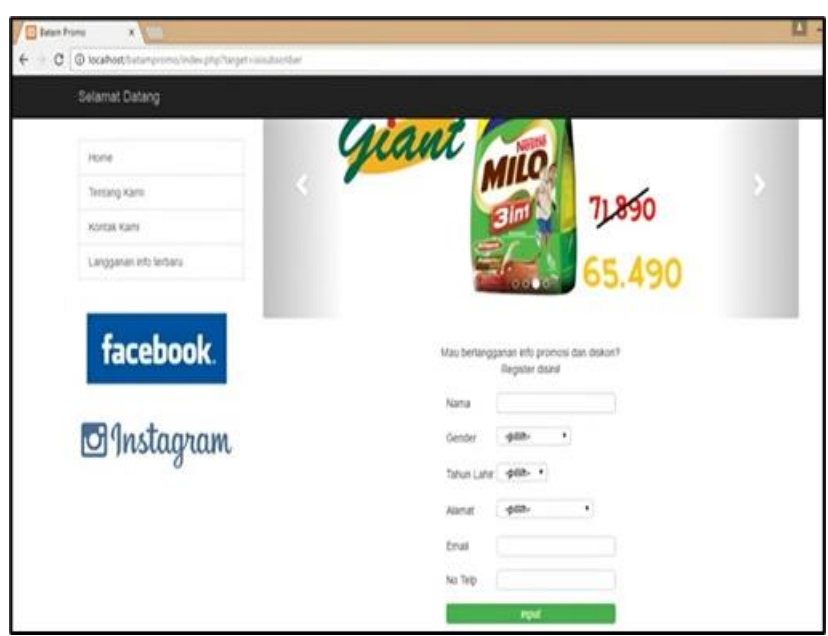

Gambar 7. Halaman input subscriber

Gambar7 merupakan tampilan halaman input subscriber, halaman ini ditujukan untuk para pengunjung yang ingin berlangganan berbagai informasi terkait promosi dan diskon di Kota Batam. Para pengunjung akan diminta untuk memasukkan berbagai data yaitu nama, gender, tahun lahir, email, no.telp. Setelah mengisi data yang diminta maka secara otomatis nanti mereka akan dikirim informasi-informasi promosi dan diskon.

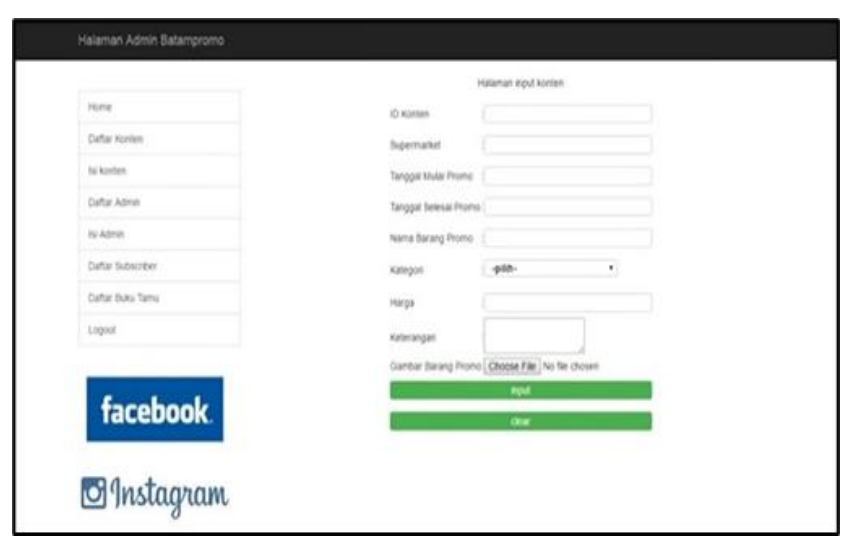

Gambar 7. Halaman input konten

Gambar 7 merupakan halaman input konten, halaman ini akan diisi oleh admin. Data-data yang akan diisi yaitu ID Konten, supermarket atau pemasar, tanggal mulai promo, tanggal selesai promo, nama barang promo, kategori, harga, keterangan dan gambar barang yang dipromo. Data-data promosi dan diskon ini akan diperoleh langsung dari pemasar, dimana pemasar akan menghubungi langsung admin. 


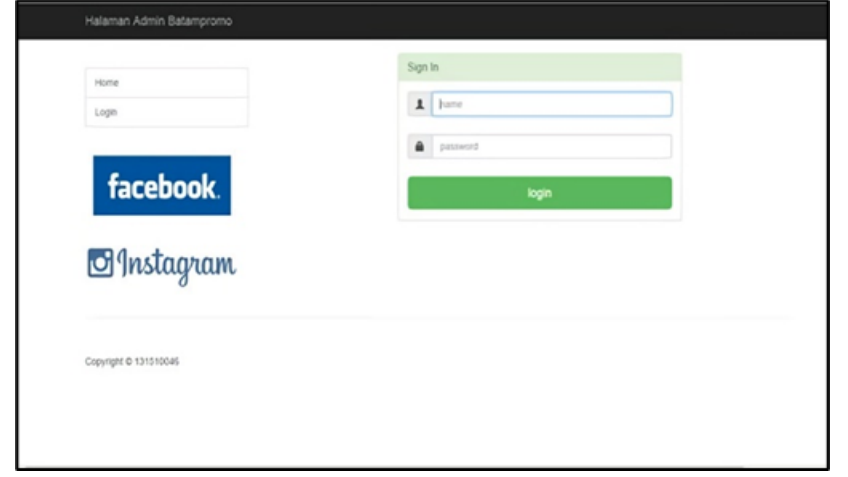

Gambar 8. Halaman input admin

Gambar 8 menunjukkan halaman input admin pada website penyedia informasi promosi dan diskon yang dibangun. Halaman ini ditujukan untuk menambahkan data-data admin apabila ada admin yang baru.

\section{B. Pembahasan}

Sistem yang dibangun yaitu website penyedia informasi promosi dan diskon mengkonversikan brosur, pamflet, spanduk dan sejenisnya ke dalam bentuk digital sehingga para pemasar tidak perlu mengeluarkan begitu banyak biaya dalam pencetakan, konsumen dan calon konsumen juga semakin dipermudah untuk memperoleh berbagai informasi terkait promosi dan diskon yang ada oleh karena itu mereka tidak perlu datang secara lansung ke lokasi retail atau toko maupun departement store. Website penyedia informasi promosi dan diskon yang dibangun terdiri dari beberapa halaman yaitu halaman login admin, halaman input buku tamu, halaman input subscriber, halaman input konten serta halaman input admin. Untuk selanjutnya website penyedia informasi promosi dan diskon ini akan dikembangkan sesuai dengan kebutuhan.

Berdasarkan analisa yang dilakukan antara sistem yang dibangun yaitu website penyedia informasi promosi dan diskon dengan sistem yang lama yaitu penyampaian promosi dan diskon secara manual maka sistem yang baru lebih efektif dan efisien. Sebagai contoh pemasar melakukan cetak brosur atau flyer Rp 150,000/1000 lembar maka ritel harus menyiapkan Rp 800,000 per bulan, cetak katalog yang berada di pintu masuk yang harganya mulai dari Rp 12,000,000/1000 lembar maka ritel harus menyiapkan sekitar Rp 12,800,000 untuk budget promosi produk, belum lagi spanduk atau baliho yang dipasang di pinggir jalan. Menggunakan website penyedia informasi promosi dan diskon maka pemasar langsung melakukan pemesanan lewat admin pengelola web dengan memberikan berbagai informasi terkait promosi dan diskon dari produk mereka, dan untuk biaya akan dikenakan sesuai tarif dan tentunya harga jauh lebih murah dibandingkan dengan promosi secara manual.

\section{KESIMPULAN}

Berdasarkan hasil penelitian yang dilakukan dan sistem dibagun yaitu website penyedia informasi promosi dan diskon selanjutnya dilakukan analisa sistem untuk membandingkan sistem yang baru dibangun dengan sistem yang lama, berdasarkan hasil analisa disimpulkan bahwa, dengan adanya website penyedia informasi promosi dan diskon maka konsumen dan calon komsumen di Kota Batam dapat dengan mudah mengetahui informasi promosi di Kota Batam tanpa harus mengunjungi secara langsung lokasi toko, retail ataupun departemen store yang sedang mengadakan promosi dan diskon sehingga mereka dapat melakukan penghematan biaya transportasi dan mereka dapat melakukan pembelian dengan cepat. Dengan adanya website penyedia informasi promosi dan diskon maka para pemasar atau pihak toko, retail ataupun departemen store dapat dengan mudah menyampaiakn informasi promosi dan diskon tanpa harus mencetak brosur, spanduk atau yang lainnya sehingga dapat mengurangi biaya operasional pemasaran. Dengan adanya website penyedia informasi promosi dan diskon ini juga maka masyarakat juga dapat menghindari keramaian sehingga terhindar dari berbagai virus serta penyakit.

\section{UCAPAN TERIMA KASIH}

Terimakasih diucapkan kepada Universitas Putera Batam yang telah mendukung terlaksananya penelitian ini, serta pihak-pihak lainnya yang tidak bisa disebutkan satupersatu semoga semua dukungan yang diberikan dapat berguna untuk orang lain.

\section{DAFTAR PUSTAKA}

[1] V. M. M. Siregar, "Perancangan Website Sebagai Media Promosi Dan Penjualan Produk," TAM (Technology Accept. Model., vol. 9, no. 1, pp. 15-21, 2018.

[2] Y. Tresnawati and K. Prasetyo, "Pemetaan Konten Promosi Digital Bisnis Kuliner kika's Catering di Media Sosial," PRofesi humas, vol. 3, no. 1, p. 102, 2018, doi: 10.24198/prh.v3i1.15333.

[3] S. Amanah, "Efektivitas Strategi Promosi Melalui Promotion MIX sebagai Upaya Penguatan Eksistensi Lembaga STAIN Kediri," Mediakita, vol. 2, no. 2, pp. 143-160, 2018, doi: 10.30762/mediakita.v2i2.987.

[4] M. A. Marzuq and A. L. Andjarwati, "LABEL PRODUK, IKLAN EMOSIONAL, DAN DISKON SERTA PENGARUHNYA TERHADAP KEPUTUSAN PEMBELIAN," J. Ilmu Manaj., vol. 8, no. 4, 2020.

[5] A. Prabarini, B. Heryanto, and P. Astutik, "Pengaruh Promosi Penjualan Dan Potongan Harga Terhadap Keputusan Pembelian Konsumen Di Toserba Borobudur Kediri (Studi Kasus Produk Kecantikan Wardah)," JIMEK, vol. 1, no. 2, pp. 259-270, 2018, doi: $10.30737 /$ jimek.v1i2.308.

[6] E. Hutabarat, "Pengaruh Promosi Dalam Meningkatkan Volume Penjualan Pada Toko Buku Gramedia Sun Plaza Medan," J. Ilm. Methonomi, vol. 3, no. 2, pp. 83-91, 2017.

[7] S. Kosasi, "Pembuatan Sistem Informasi Penjualan Berbasis Web Untuk Memperluas Pangsa Pasar," Pros. SNATIF Ke-1, pp. 225-232, 2014.

[8] D. S. Puspitarini and R. Nuraeni, "PEMANFAATAN MEDIA SOSIAL SEBAGAI MEDIA PROMOSI (Studi Deskriptif pada Happy Go Lucky House)," J. Common, vol. 3, no. 1, pp. 71-80, 2019, doi: 10.34010/common.v3i1.1950.

[9] Q. Ayuni, H. Cangara, and Arianto, "PENGARUH PENGGUNAAN MEDIA DIGITAL TERHADAP TINGKAT PENJUALAN PRODUK KULINER KEMASAN THE INFLUENCE OF DIGITAL MEDIA USE ON SALES LEVEL OF CULINARY PACKAGE PRODUCT AMONG FEMALE," J. Penelit. Komun. dan Opini Publik, vol. 23, no. 2, pp. 129-141, 2019.

[10] L. Moriansyah, "Pemasaran Melalui Media Sosial: Antecedents Dan Consequences," J. Penelit. Komun. dan Opini Publik, vol. 19, no. 3, pp. 187-196, 2015.

[11] Z. Umami, "Social Strategy Pada Media Sosial Untuk Promosi Pariwisata Daerah Istimewa Yogyakarta," J. Interak., vol. 4, no. 2, pp. 195-201, 2015, doi: 10.14710/interaksi,4,2,195-201.

[12] S. K. DEWI and A. K. GARSIDE, "PERANCANGAN 
WEbSITE SEBAGAI MEDIA PROMOSI DAN PENJUALAN PADA HOME INDUSTrY ABON," J. Tek. Ind., vol. 15, no. 2, p. 170, 2014, doi: 10.22219/jtiumm.vol15.no2.170-181.

[13] A. Fajrin, "PENGARUH PROMOSI PENJUALAN DAN ESERVICE QUALITY TERHADAP KEPUTUSAN PENGGUNAAN APLIKASI OVO,” J. Ris. Manaj. Sains Indones., vol. 11, no. 2, pp. 201-223, 2020.

[14] G. W. Sasmito, "Penerapan Metode Waterfall Pada Desain Sistem Informasi Geografis Industri Kabupaten Tegal," $J$. Inform. Pengemb. IT, vol. 2, no. 1, pp. 6-12, 2017.

[15] A. Rifai and Y. P. Yuniar, "Penerapan Metode Waterfall Dalam Perancangan Sistem Informasi Ujian Pada SMK Indonesia Global Berbasis Web," J. Khatulistiwa Inform., vol. 7, no. 1, pp. 1-6, 2019, doi: 10.31294/jki.v7i1.64. 